\title{
Findings from Diet Comparison Difficult to Interpret in the Absence of Adherence Assessment. Comment on Tricò et al. Effects of Low-Carbohydrate versus Mediterranean Diets on Weight Loss, Glucose Metabolism, Insulin Kinetics and $\beta$-Cell Function in Morbidly Obese Individuals. Nutrients 2021, 13,1345
}

\author{
Matthew J. Landry $(\mathbb{D}$, Anthony Crimarco $(D)$ and Christopher D. Gardner * $\mathbb{D}$ \\ Stanford Prevention Research Center, Department of Medicine, School of Medicine, Stanford University, \\ Stanford, CA 94305, USA; matthewlandry@stanford.edu (M.J.L.); crimarco@stanford.edu (A.C.) \\ * Correspondence: cgardner@stanford.edu
}

check for updates

Citation: Landry, M.J.; Crimarco, A.; Gardner, C.D. Findings from Diet Comparison Difficult to Interpret in the Absence of Adherence

Assessment. Comment on Tricò et al. Effects of Low-Carbohydrate versus Mediterranean Diets on Weight Loss, Glucose Metabolism, Insulin Kinetics and $\beta$-Cell Function in Morbidly Obese Individuals. Nutrients 2021, 13 , 1345. Nutrients 2021, 13, 3694 https://doi.org/10.3390/nu13113694

Academic Editor: Mario Barbagallo

Received: 28 May 2021

Accepted: 25 August 2021

Published: 21 October 2021

Publisher's Note: MDPI stays neutral with regard to jurisdictional claims in published maps and institutional affiliations.

Copyright: () 2021 by the authors. Licensee MDPI, Basel, Switzerland. This article is an open access article distributed under the terms and conditions of the Creative Commons Attribution (CC BY) license (https:// creativecommons.org/licenses/by/ $4.0 /)$.
We read, with interest, the recent publication by Tricò et al. on the effectiveness of two calorie-restricted eating patterns on weight loss and glucose homeostasis in individuals with morbid obesity and insulin-resistance [1]. The authors address a timely topic. However, we feel there are important limitations worth noting that impact the validity of the study's overall findings.

When interpreting studies comparing different dietary patterns, adherence to assigned diets is a critical factor to consider [2]. As designed, the parallel arms in this study compared a Mediterranean diet (55\% carbohydrate, $15 \%$ protein, and $30 \%$ fat) to a low-carbohydrate $\operatorname{diet}(30 \%$ carbohydrate, $30 \%$ protein, and $40 \%$ fat), with calorie restriction tailored to be $50 \%$ of estimated resting energy expenditure [1]. Adherence to study diets was determined to be adequate given that "actual weight loss was close to the predicted". This is not an appropriate approach to assessment of adherence.

As we have recently discussed, it is common for participants to have difficulty achieving prescribed research diets in a free-living setting, which makes reporting the actual dietary intake and assessing adherence critical for interpretation [2]. Greater dietary adherence, regardless of the type of diet, is an important factor in weight-loss success and maintenance [3-5]. We recently conducted an intervention trial comparing a lowcarbohydrate (ketogenic) and a Mediterranean diet in which we published a separate methods and adherence paper [6]. Even when we were providing participants with a food delivery service for 4 weeks to maximize adherence to their research diets we observed a wide range of adherence variability among participants; overall adherence was shown to be similar, increasing internal validity.

It is notable that the design of the study diets likely involved an inherent difference in engagement or effort to achieve adherence. Although baseline diet of participants was not reported, it appears likely the low-carbohydrate diet arm involved more extensive changes from usual diet relative to the Mediterranean diet arm. This raises the concern that differences in study outcomes between the two diet groups could be attributable to more than just the nutrient composition-differential engagement might explain some of the between diet differences $[2,5]$.

Lastly, an additional key aspect for interpretation of broader generalizability is an assessment of the relative satisfaction of participants with their assigned diets. We feel it's a missed opportunity for Tricò et al. to not report on the satisfaction participants have with study diets or on other potentially relevant individual-level factors (e.g., cost, familiarity). The practical implications for motivating food factors and values within interventions has 
been recently examined by Eustis and colleagues [7]. In our own trials, we have found varying psychosocial, demographic, and environmental motivational factors regarding adherence to study diets $[6,8,9]$.

We hope that these comments stimulate a greater discussion by interventionists of strategies and assessments related to dietary adherence, and that they may want to incorporate these comments into future nutrition intervention studies.

Author Contributions: Conceptualization, M.J.L. and A.C.; writing-original draft preparation, M.J.L. and A.C.; writing-review and editing, M.J.L., A.C., and C.D.G.; supervision, C.D.G. All authors have read and agreed to the published version of the manuscript.

Funding: M.J.L. and A.C. were supported by National Heart, Lung, and Blood Institute grant NIH T32HL007034.

Institutional Review Board Statement: Not applicable.

Informed Consent Statement: Not applicable.

Data Availability Statement: Not applicable.

Conflicts of Interest: The authors declare no conflict of interest.

\section{References}

1. Tricò, D.; Moriconi, D.; Berta, R.; Baldi, S.; Quinones-Galvan, A.; Guiducci, L.; Taddei, S.; Mari, A.; Nannipieri, M. Effects of Low-Carbohydrate versus Mediterranean Diets on Weight Loss, Glucose Metabolism, Insulin Kinetics and $\beta$-Cell Function in Morbidly Obese Individuals. Nutrients 2021, 13, 1345. [CrossRef]

2. Gardner, C.D.; Crimarco, A.; Landry, M.J.; Fielding-Singh, P. Nutrition Study Design Issues-Important Issues for Interpretation. Am. J. Health Promot. 2020, 34, 951-954. [CrossRef] [PubMed]

3. Alhassan, S.; Kim, S.; Bersamin, A.; King, A.; Gardner, C. Dietary adherence and weight loss success among overweight women: Results from the A TO Z weight loss study. Int. J. Obes. 2008, 32, 985-991. [CrossRef] [PubMed]

4. Del Corral, P.; Bryan, D.R.; Garvey, W.T.; Gower, B.A.; Hunter, G.R. Dietary adherence during weight loss predicts weight regain. Obesity 2011, 19, 1177-1181. [CrossRef] [PubMed]

5. Gibson, A.A.; Sainsbury, A. Strategies to improve adherence to dietary weight loss interventions in research and real-world settings. Behav. Sci. 2017, 7, 44. [CrossRef] [PubMed]

6. Landry, M.J.; Crimarco, A.; Perelman, D.; Durand, L.R.; Petlura, C.; Aronica, L.; Robinson, J.L.; Kim, S.H.; Gardner, C.D. Adherence to Ketogenic and Mediterranean Study Diets in a Crossover Trial: The Keto-Med Randomized Trial. Nutrients 2021, 13, 967. [CrossRef] [PubMed]

7. Eustis, S.J.; Turner-McGrievy, G.; Adams, S.A.; Hébert, J.R. Measuring and Leveraging Motives and Values in Dietary Interventions. Nutrients 2021, 13, 1452. [CrossRef] [PubMed]

8. Aronica, L.; Rigdon, J.; Offringa, L.C.; Stefanick, M.L.; Gardner, C.D. Examining differences between overweight women and men in 12-month weight loss study comparing healthy low-carbohydrate vs. low-fat diets. Int. J. Obes. 2021, 45, 225-234. [CrossRef] [PubMed]

9. Fielding-Singh, P.; Patel, M.L.; King, A.C.; Gardner, C.D. Baseline psychosocial and demographic factors associated with study attrition and 12-month weight gain in the DIETFITS trial. Obesity 2019, 27, 1997-2004. [CrossRef] [PubMed] 